\title{
Epi-reevesioside $\mathbf{F}$ inhibits $\mathrm{Na}^{+} / \mathrm{K}^{+}-\mathrm{ATPase}$, causing cytosolic acidification, Bak activation and apoptosis in glioblastoma
}

\author{
Jui-Ling Hsu ${ }^{1}$, Fan-Lun Liu ${ }^{1}$, Lih-Ching Hsu ${ }^{1}$, Hsun-Shuo Chang ${ }^{2,3}$, Wohn-Jenn \\ Leu ${ }^{1}$, Chia-Chun $\mathrm{Yu}^{1}$, Wei-Ling Chang ${ }^{4}$, Ih-Sheng Chen ${ }^{2,3}$, Fan-Lu Kung ${ }^{1}$ and Jih- \\ Hwa Guh ${ }^{1}$ \\ 1 School of Pharmacy, National Taiwan University, Taipei, Taiwan \\ ${ }^{2}$ School of Pharmacy, College of Pharmacy, Kaohsiung Medical University, Kaohsiung, Taiwan \\ ${ }^{3}$ Graduate Institute of Natural Products, College of Pharmacy, Kaohsiung Medical University, Kaohsiung, Taiwan \\ ${ }^{4}$ The Division of Medicinal Chemistry, College of Pharmacy, The Ohio State University, Columbus, OH, USA \\ Correspondence to: Jih-Hwa Guh, email: jhguh@ntu.edu.tw \\ Fan-Lu Kung, email: flkung@ntu.edu.tw
}

Keywords: Epi-reevesioside $\mathrm{F}$, intracellular $\mathrm{Na}^{+}$concentration, cytosolic acidification, mitochondrial dysfunction, bak activation Received: March 23, 2015

Accepted: June 04, 2015

Published: June 10, 2015

This is an open-access article distributed under the terms of the Creative Commons Attribution License, which permits unrestricted use, distribution, and reproduction in any medium, provided the original author and source are credited.

\section{ABSTRACT}

Epi-reevesioside F, a new cardiac glycoside isolated from the root of Reevesia formosana, displayed potent activity against glioblastoma cells. Epi-reevesioside $F$ was more potent than ouabain with $\mathrm{IC}_{50}$ values of $27.3 \pm 1.7 \mathrm{vs} .48 .7 \pm 1.8 \mathrm{nM}(P<$ $0.001)$ and $45.0 \pm 3.4$ vs. $81.3 \pm 4.3 \mathrm{nM}(P<0.001)$ in glioblastoma T98 and U87 cells, respectively. However, both Epi-reevesioside $F$ and ouabain were ineffective in $A 172$ cells, a glioblastoma cell line with low $\mathrm{Na}^{+} / \mathrm{K}^{+}-$ATPase a 3 subunit expression. Epireevesioside $F$ induced cell cycle arrest at $S$ and $\mathbf{G} 2$ phases and apoptosis. It also induced an increase of intracellular concentration of $\mathrm{Na}^{+}$but not $\mathrm{Ca}^{2+}$, cleavage and exposure of $\mathbf{N}$-terminus of Bak, loss of mitochondrial membrane potential, inhibition of Akt activity and induction of caspase cascades. Potassium supplements significantly inhibited Epi-reevesioside F-induced effects. Notably, Epi-reevesioside F caused cytosolic acidification that was highly correlated with the anti-proliferative activity. In summary, the data suggest that Epi-reevesioside $\mathrm{F}$ inhibits $\mathrm{Na}^{+} / \mathrm{K}^{+}$-ATPase, leading to overload of intracellular $\mathrm{Na}^{+}$and cytosolic acidification, Bak activation and loss of mitochondrial membrane potential. The PI3-kinase/Akt pathway is inhibited and caspase-dependent apoptosis is ultimately triggered in Epi-reevesioside F-treated glioblastoma cells.

\section{INTRODUCTION}

Cardiac glycosides are a class of steroid-like compounds and have a long history in the treatment of cardiac diseases, such as congestive heart failure and arrhythmia. Inhibition of $\mathrm{Na}^{+} / \mathrm{K}^{+}$-ATPase by cardiac glycosides leads to intracellular $\mathrm{Na}^{+}$overload which in turn drives $\mathrm{Ca}^{2+}$ influx into cells [1]. Appropriate increase of intracellular $\mathrm{Ca}^{2+}$ levels in cardiac cells results in an increase of contractility. However, intracellular $\mathrm{Ca}^{2+}$ overload may cause cell death since $\mathrm{Ca}^{2+}$ participates in signaling pathways of apoptosis and necrosis [2]. Because of the pivotal role in deciding cell fate, disturbance of $\mathrm{Ca}^{2+}$ homeostasis can be an anticancer strategy. It has been documented that cardiac glycosides, including bufotalin, oleandrin, ouabain and digoxin and their derivatives, induce anti-proliferative and apoptotic activities in cancer cells through an increase of intracellular $\mathrm{Ca}^{2+}$ levels [35]. $\mathrm{Ca}^{2+}$-independent signaling pathways also have been reported, such as oxidative stress [6], inhibition of NF$\kappa \mathrm{B}$ and AP-1 [7], an increase of FasL expression [7, 8], inhibition of topoisomerases [3], and down-regulation of pro-survival Bcl-2 family members [9] and protooncogene $c$-myc expression $[10,11]$.

Ion transport and intracellular $\mathrm{pH}$ are important in numerous cell functions, including cell membrane 
potential, cell volume, mitochondrial function, enzyme activity, DNA synthesis, cell proliferation, differentiation, oncogenesis, malignant transformation and metastasis $[12,13]$. Aberrant regulation of $\mathrm{H}^{+}$dynamics occurs in almost all tumors. Tumors, by using multiple ways for ion transport, create extracellular acid microenvironment while maintain alkaline intracellular $\mathrm{pH}$, promoting survival, progression and metastasis [12-14]. Alkaline intracellular $\mathrm{pH}$ also contributes to chemotherapy resistance $[15,16]$. Establishment of this self-defensive/ anti-apoptotic mechanism is predominantly through antiacidifying effect caused by hyperactivity of membranebound $\mathrm{H}^{+}$extrusion transporters [17]. Many studies have suggested that intracellular acidification resulted from chemotherapeutic drugs is responsible for an early onset of malignant cell apoptosis [17-19]. Accordingly, $\mathrm{H}^{+}$ extrusion transporters are potential targets for anticancer strategy [17].

Recently, bioassay-guided fractionation of the root of Reevesia formosana resulted in the isolation of new cardiac glycosides with anti-proliferative and apoptotic activities in our work $[11,20,21]$. In this study, Epireevesioside $\mathrm{F}$ has been examined to display potent antiproliferative activity in glioblastoma cells, leading to Bak activation, mitochondrial dysfunction and cell death. The signaling pathways related to ion transport and cytosolic acidification have been identified to demonstrate the anticancer potential of Epi-reevesioside F.

\section{RESULTS}

\section{Epi-reevesioside F displays anti-proliferative activity against both $\mathrm{T} 98$ and $\mathrm{U} 87$ cells}

Both Epi-reevesioside $\mathrm{F}$ and ouabain induced concentration-dependent inhibition of cell proliferation in T98 and U87 cells using sulforhodamine B assay. Epireevesioside $\mathrm{F}$ was more potent than ouabain with $\mathrm{IC}_{50}$ values of $27.3 \pm 1.7$ vs. $48.7 \pm 1.8 \mathrm{nM}(P<0.001)$ and $45.0 \pm 3.4$ vs. $81.3 \pm 4.3 \mathrm{nM}(P<0.001)$ in T98 and U87 cells, respectively (Figure 1A). Both compounds were ineffective in A172 cells. Cardiac glycosides have been suggested to show distinct affinities toward $\mathrm{Na}^{+} / \mathrm{K}^{+}$ATPase $\alpha$-isoforms [22]. The detection of $\alpha$-isoforms protein levels demonstrated that the expression of $\alpha 3$ subunit was much lower in A172 than that in T98 and U87 cells (Figure 1B). Several cell lines were also examined with varied expression levels of $\mathrm{Na}^{+} / \mathrm{K}^{+}$-ATPase $\alpha 3$ subunit (Figure 1B). Epi-reevesioside F-induced antiproliferative effects were identified to have a high correlation $\left(r^{2}=0.96\right)$ with $\alpha 3$-subunit expressions. The inhibition of cell proliferation was further confirmed by CFSE assay. The data in Figure 1C demonstrated that the major population was the second and the third generation after seeding cells for 24 and 48 h, respectively. However, the population distribution significantly shifted to the parent and the second generation after the exposure to Epi-reevesioside F, respectively, confirming its antiproliferative activity (Figure 1C).

\section{Epi-reevesioside $\mathbf{F}$ induces cell cycle arrest and differential apoptotic regulation between $\mathrm{T98}$ and U87 cells}

Flow cytometric analysis of propidium iodide staining revealed that both Epi-reevesioside F and ouabain induced concentration-dependent arrest of cell cycle at $\mathrm{S}$ and $\mathrm{G} 2 / \mathrm{M}$ phases associated with apoptosis in T98 cells (Figure 2A). In contrast, only a moderate increase of G2/M phase arrest was triggered in U87 cells (Figure 2B). DNA damage or DNA replication stress can activate several key kinases that induce cell cycle arrest predominantly at $\mathrm{S}$ and G2 phases to facilitate DNA repair [23]. Several downstream targets induced by DNA damage were examined, including Chk kinase, $\gamma$-H2A.X and replication protein A (RPA, protein complex associating with singlestranded DNA). The data showed that Epi-reevesioside F did not stimulate these cellular targets (Supplementary Figure 1) indicating that DNA was not a primary target for Epi-reevesioside F.

\section{Epi-reevesioside $\mathbf{F}$ increases intracellular $\mathrm{Na}^{+}$ concentrations}

Several lines of evidence have suggested that cells may accumulate in G1/S and G2 phases under hyperosmotic stress [24, 25]. Because Epi-reevesioside $\mathrm{F}$ induced cell cycle arrest at both $\mathrm{S}$ and $\mathrm{G} 2 / \mathrm{M}$ phases and inhibited cell proliferation, the intracellular $\mathrm{Na}^{+}$ concentrations were examined. The data demonstrated that both Epi-reevesioside F and ouabain caused significant increases of intracellular $\mathrm{Na}^{+}$concentrations (Figure 3A), which were almost completely abolished by extracellular potassium supplements (Figure 3B). Furthermore, both Epi-reevesioside F- and ouabain-induced inhibition of cell proliferation in T98 and U87 cells was significantly rescued by extracellular potassium supplements (Figure 4).

The rise of intracellular $\mathrm{Na}^{+}$concentrations induced by inhibition of $\mathrm{Na}^{+} / \mathrm{K}^{+}$-ATPase may drive the influx of $\mathrm{Ca}^{2+}$ through $\mathrm{Na}^{+} / \mathrm{Ca}^{2+}$ exchange system [1]. Intracellular $\mathrm{Ca}^{2+}$ overload can lead to cell death because $\mathrm{Ca}^{2+}$ participates in a variety of cell death programs [2]. Flow cytometric analysis of fluo-3 staining showed that both Epi-reevesioside $\mathrm{F}$ and ouabain did not modify intracellular $\mathrm{Ca}^{2+}$ concentrations (Supplementary Figure 2). 
A

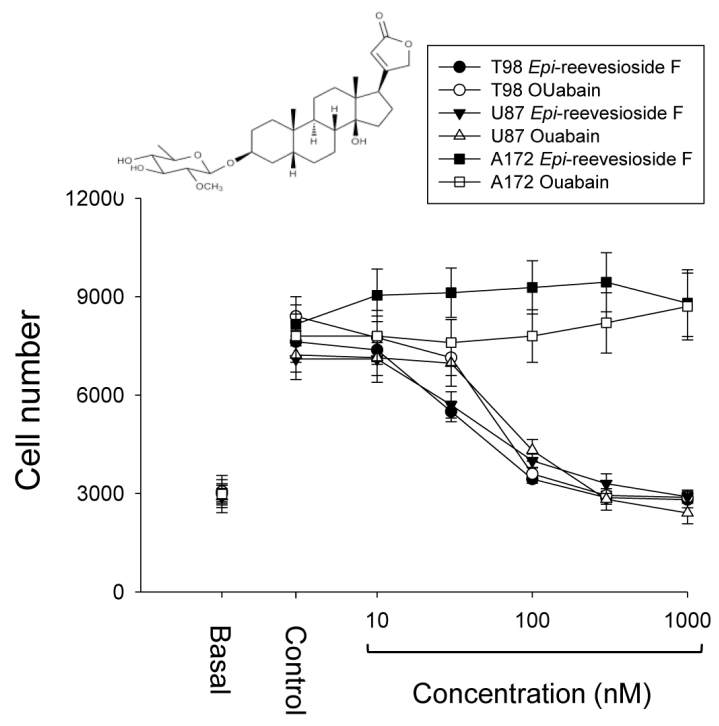

B

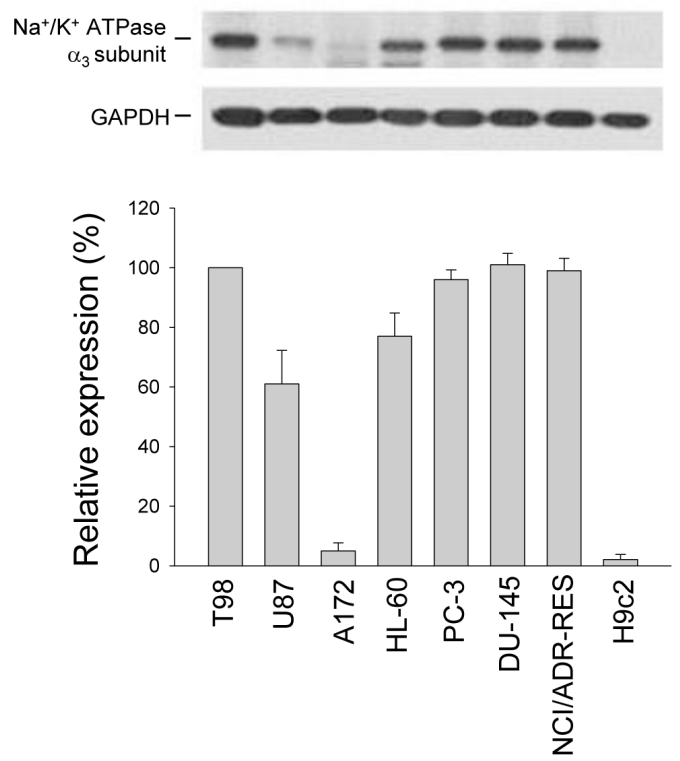

C

Control

$\mathrm{Oh}$

$24 \mathrm{~h}$

$48 \mathrm{~h}$
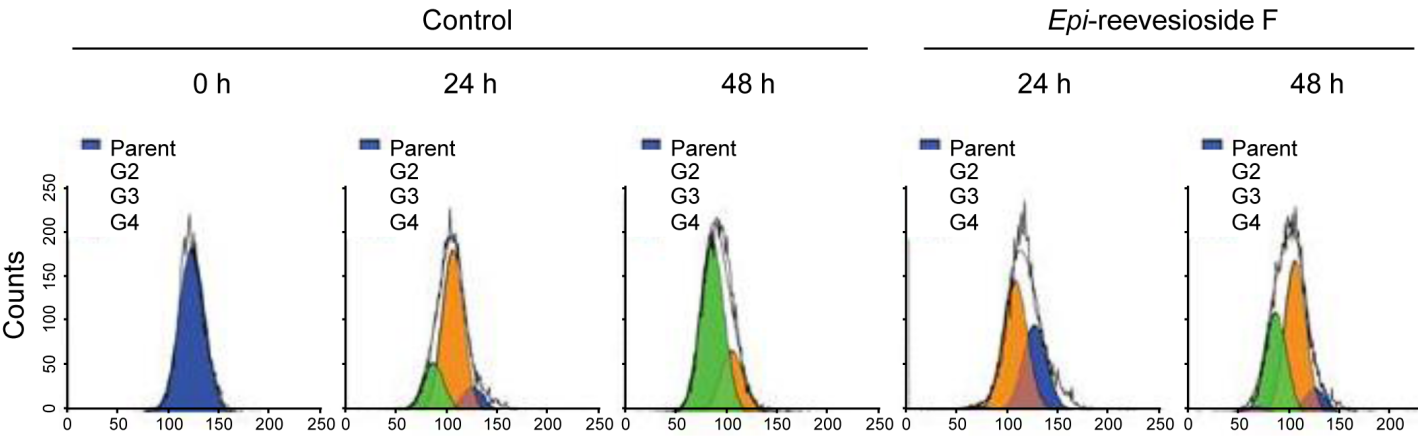

FL1-H

FL1-H
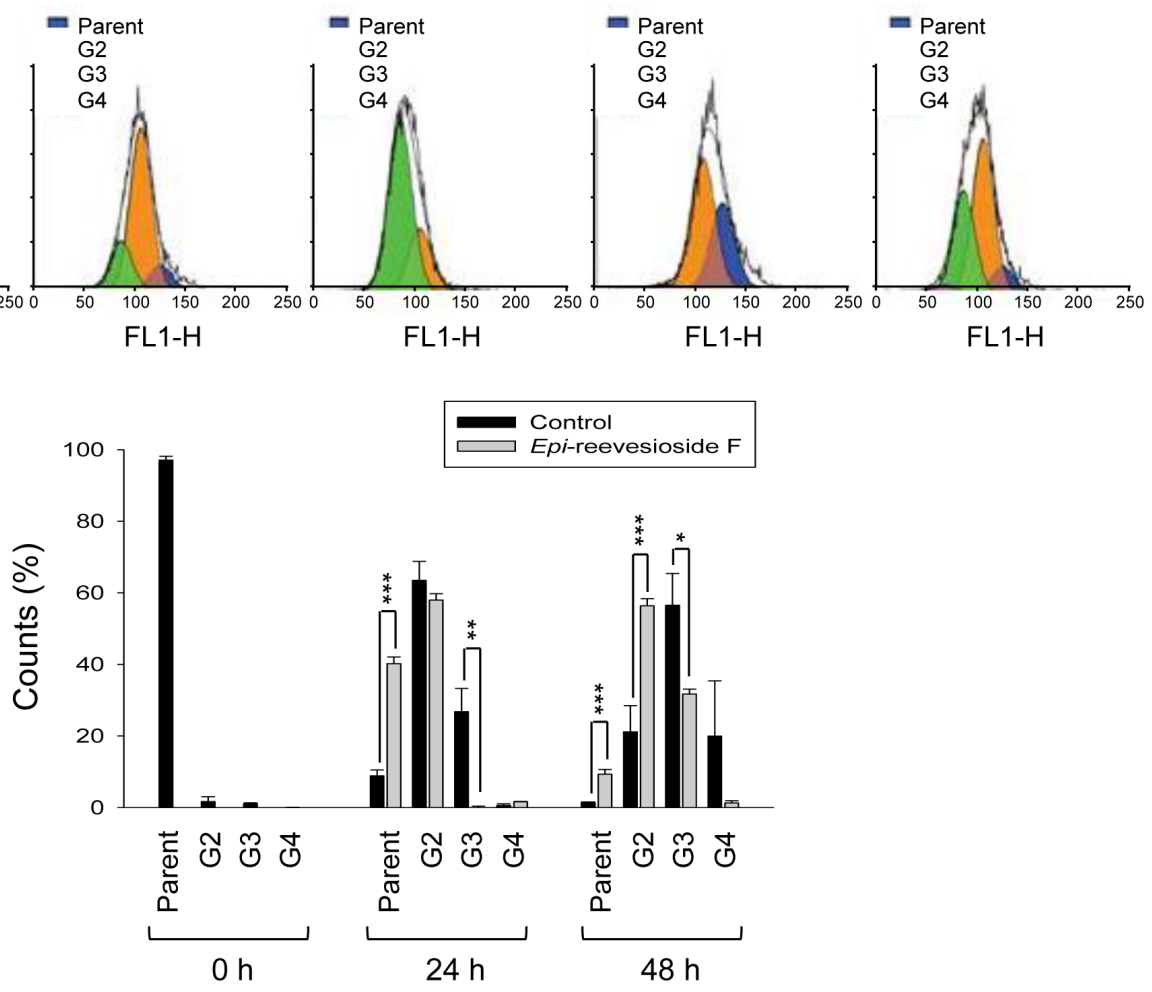

Figure 1: Effect of Epi-reevesioside $\mathrm{F}$ on cell proliferation and protein expression of $\mathrm{Na}^{+} / \mathrm{K}^{+}$-ATPase $\alpha 3$ subunit. (A) The graded concentrations of Epi-reevesioside F and ouabain were added to the cells for 48 hours (T98 and A172 cells) or 72 hours (U87 cells). After the treatment, cell proliferation was determined using sulforhodamine B assay. (B) The cells were lysed for the detection of protein expression by Western blot analysis. The expression was quantified using computerized image analysis system ImageQuant (Amersham Biosciences). (C) T98 cells were incubated in the absence of presence of Epi-reevesioside F (100 nM) for the indicated time. After treatment, the cells were fixed and labeled with CFSE for flow cytometric analysis. Data are expressed as mean \pm SEM of three to five independent determinations. $* P<0.05, * * P<0.01$ and ${ }^{* * *} P<0.001$ compared with the parent cells. 


\section{Epi-reevesioside F decreases intracellular $\mathrm{pH}$ and inhibits cell proliferation}

The relationship between changes in intracellular $\mathrm{pH}$ and cell proliferation has attracted attention in anticancer researches. It has been suggested that cytoplasmic acidification may blunt proliferation and promote apoptosis in various cancer cell lines through a decrease of protein synthesis and influence of signaling pathways which govern cell survival [26, 27]. Flow cytometric analysis of fluorescent dye seminaphtharhodafluor-1 staining showed that Epi-reevesioside F induced timeand concentration-dependent intracellular acidification in T98 cells (Figure 5A). Confocal microscopic examination also demonstrated similar intracellular $\mathrm{pH}$-lowering effect (Figure 5B). The correlation between intracellular $\mathrm{pH}$ and cell proliferation was determined with a high correlation coefficient $\left(\mathrm{r}^{2}=0.98\right.$, Supplementary Figure 3$)$, revealing that intracellular acidity could be a key factor in Epi-

A
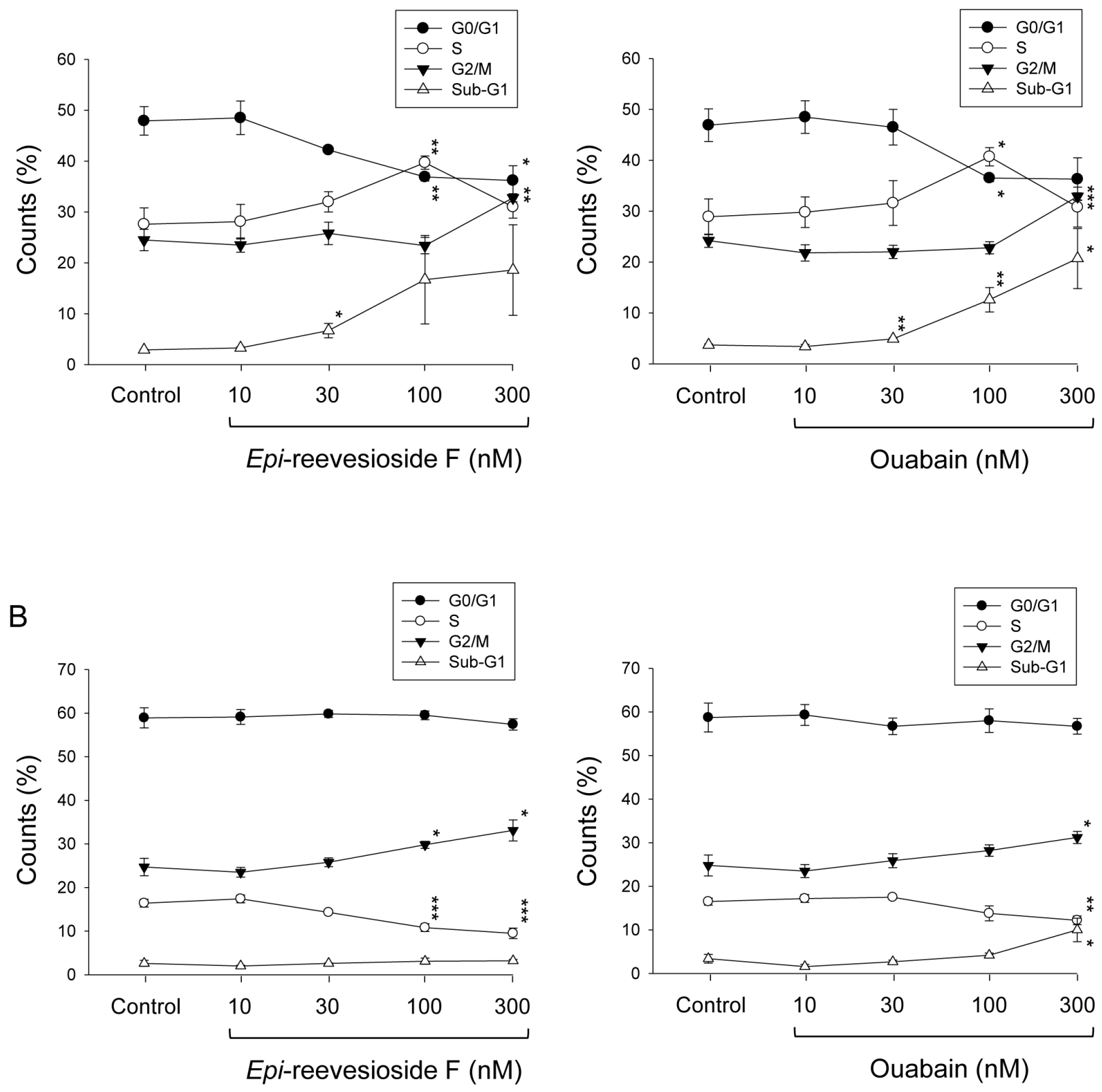

Figure 2: Effect of Epi-reevesioside F and ouabain on cell-cycle progression. T98 (A) or U87 (B) cells were incubated in the absence or presence of Epi-reevesioside F or ouabain for 48 hours. After the treatment, the cells were harvested for the determination of cell cycle population using the detection of DNA content analyzed with FACScan and CellQuest software. Data are expressed as mean \pm SEM of three independent determinations. ${ }^{*} P<0.05, * * P<0.01$ and $* * * P<0.001$ compared with the respective control. 

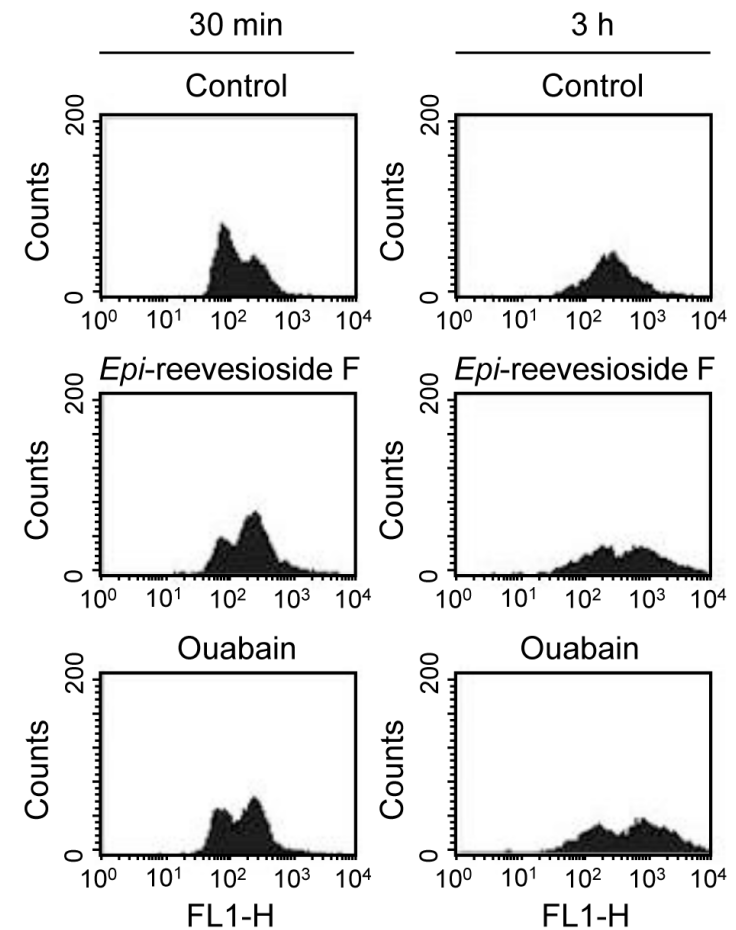

B
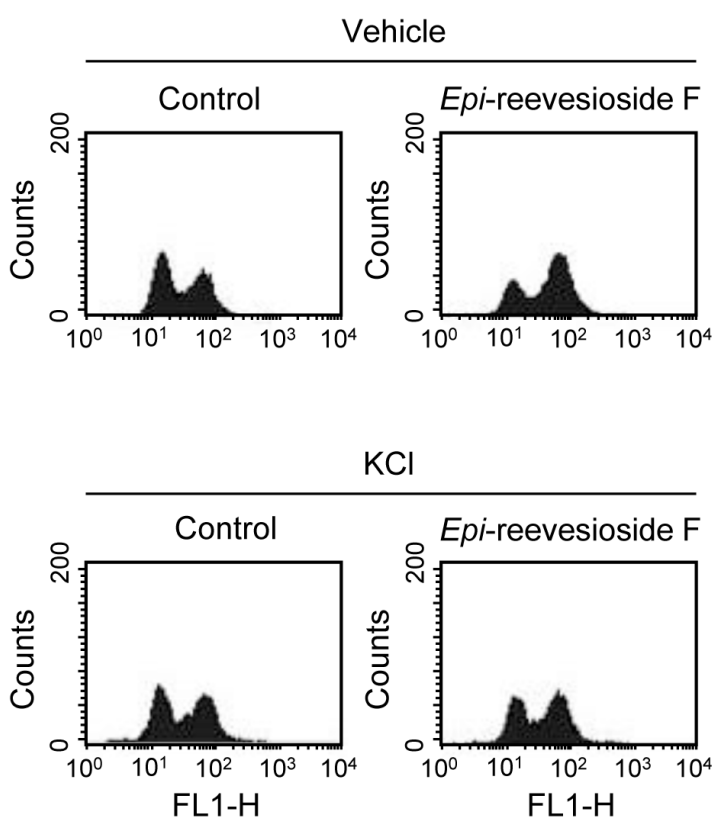

$\mathrm{KCl}$

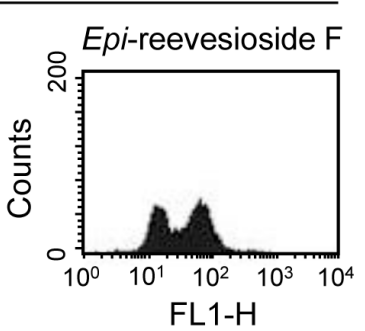

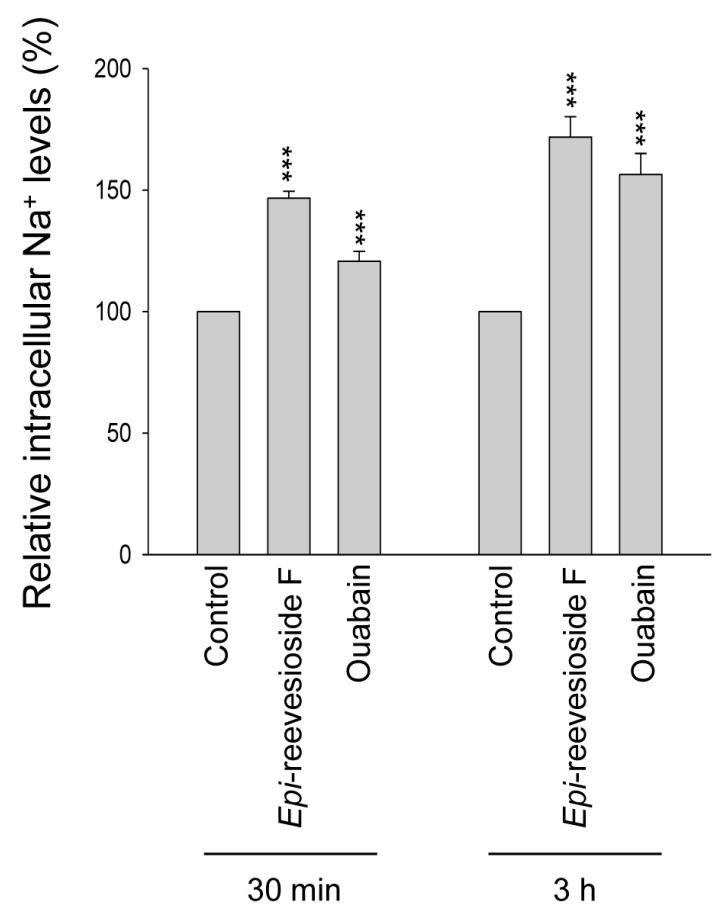

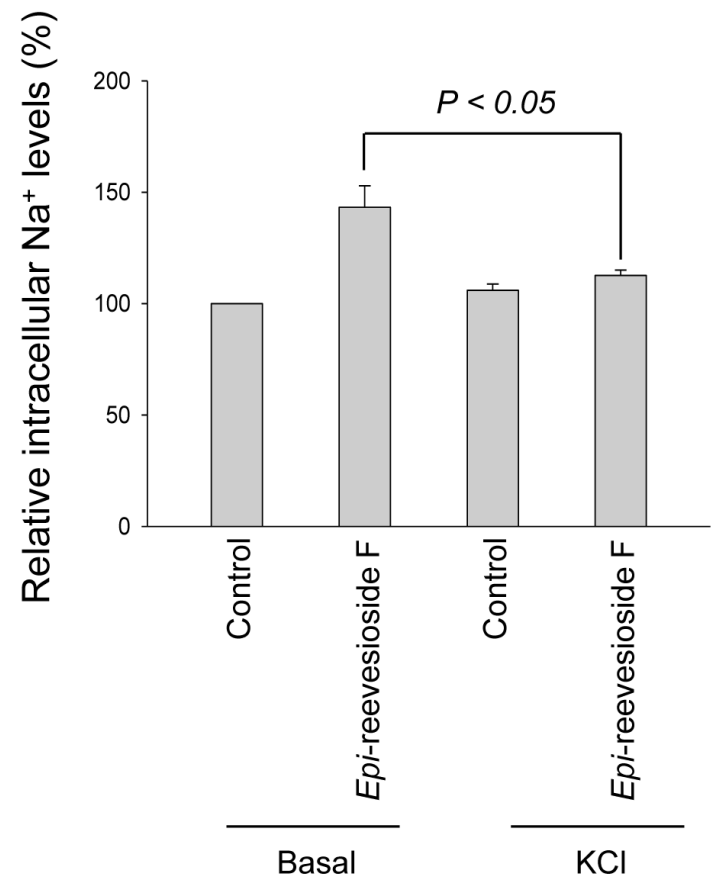

Figure 3: Effect of Epi-reevesioside $\mathbf{F}$ and ouabain on intracellular $\mathbf{N a}^{+}$levels. (A) T98 cells were incubated in the absence or presence of Epi-reevesioside F $(100 \mathrm{nM})$ or ouabain $(100 \mathrm{nM})$ for the indicated time, or (B) T98 cells were incubated in the absence or presence of Epi-reevesioside F $(100 \mathrm{nM})$ with or without extracellular potassium supplements $(10.7 \mathrm{mM})$ for 3 hours. After the treatment, the intracellular $\mathrm{Na}^{+}$levels were examined using flow cytometric analysis. Data are expressed as mean $\pm \mathrm{SEM}$ of three to five independent determinations. $* * * P<0.001$ compared with the respective control. 

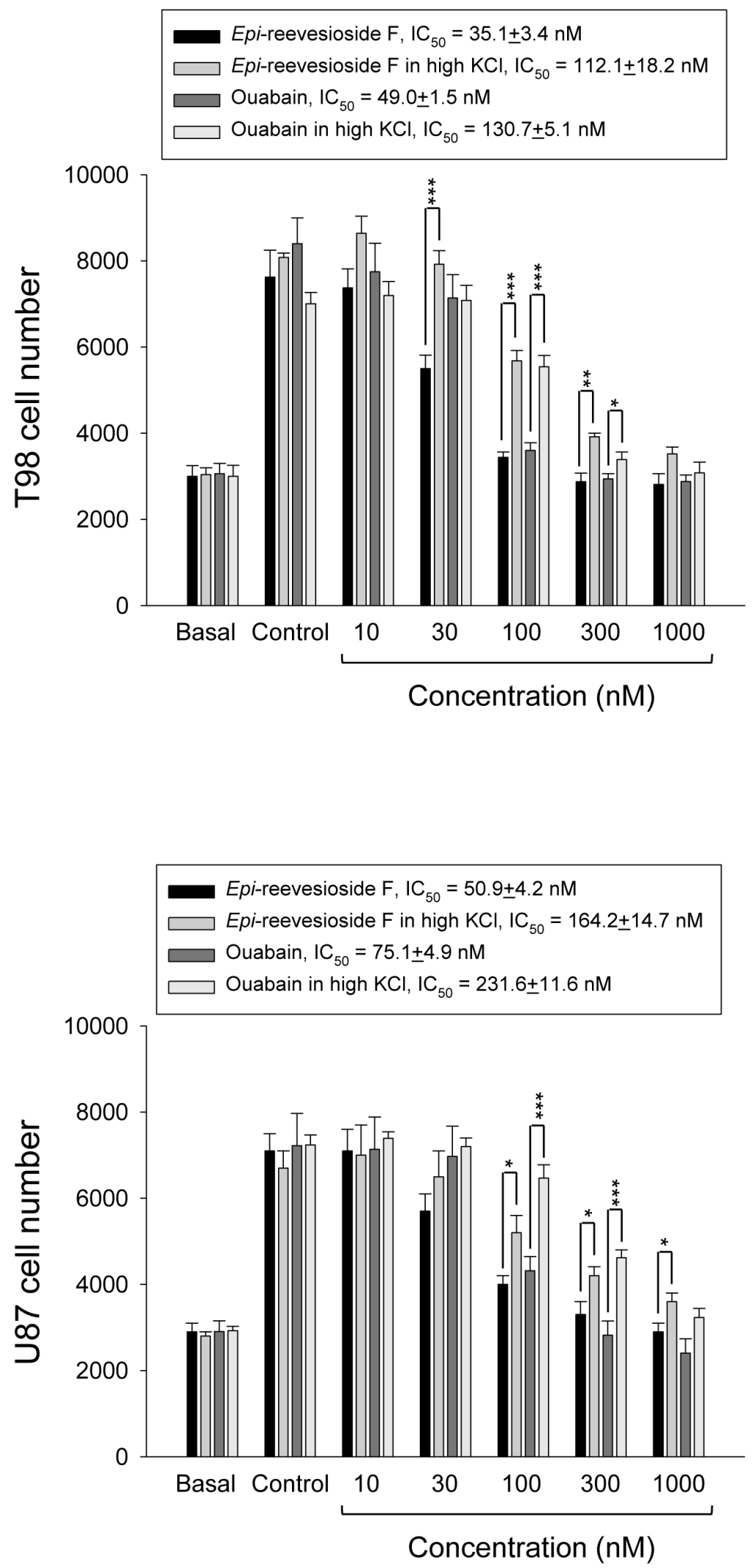

Figure 4: Effect of potassium supplements on cardiac glycoside-induced anti-proliferation. T98 or U87 cells were incubated in the absence or presence of Epi-reevesioside F or ouabain for 48 hours (T98) or 72 hours (U87) with or without extracellular potassium supplements $(10.7 \mathrm{mM})$. After the treatment, cell proliferation was determined using sulforhodamine B assay. Data are expressed as mean \pm SEM of four to five independent determinations. $* P<0.05, * * P<0.01$ and $* * * P<0.001$ compared with cardiac glycoside alone. 
reevesioside F-induced effect.

Sodium/hydrogen exchangers (NHEs) constitute a large family of integral membrane protein transporters responsible for counter transport of $\mathrm{H}^{+}$and $\mathrm{Na}^{+}$. The expression of NHE isoform 1 (NHE1) is ubiquitous. NHE1 activation is sensitive to intracellular acidic $\mathrm{pH}$ and is rapidly induced upon a drop of cytosolic $\mathrm{pH}$ [28]. The effect of Epi-reevesioside F on NHE1 activity was studied using immunoprecipitation analysis because the binding of 14-3-3 to NHE1 has been identified to be associated with the activation of $\mathrm{Na}^{+} / \mathrm{H}^{+}$exchange [29]. As a result, Epi-reevesioside F significantly increased the association between NHE1 and 14-3-3, indicating an increase of
NHE1 activity (Supplementary Figure 4). The data support the intracellular acidification to Epi-reevesioside F action.

\section{Epi-reevesioside F induces mitochondrial damage and caspase-dependent apoptosis}

Intracellular acidification has been suggested to be responsible for mitochondrial dysfunction and both caspase-dependent and -independent apoptosis under several apoptotic stimuli [30]. Furthermore, a decrease of intracellular $\mathrm{pH}$ may stimulate several acid DNases to promote cell death in many apoptotic conditions [31].

A
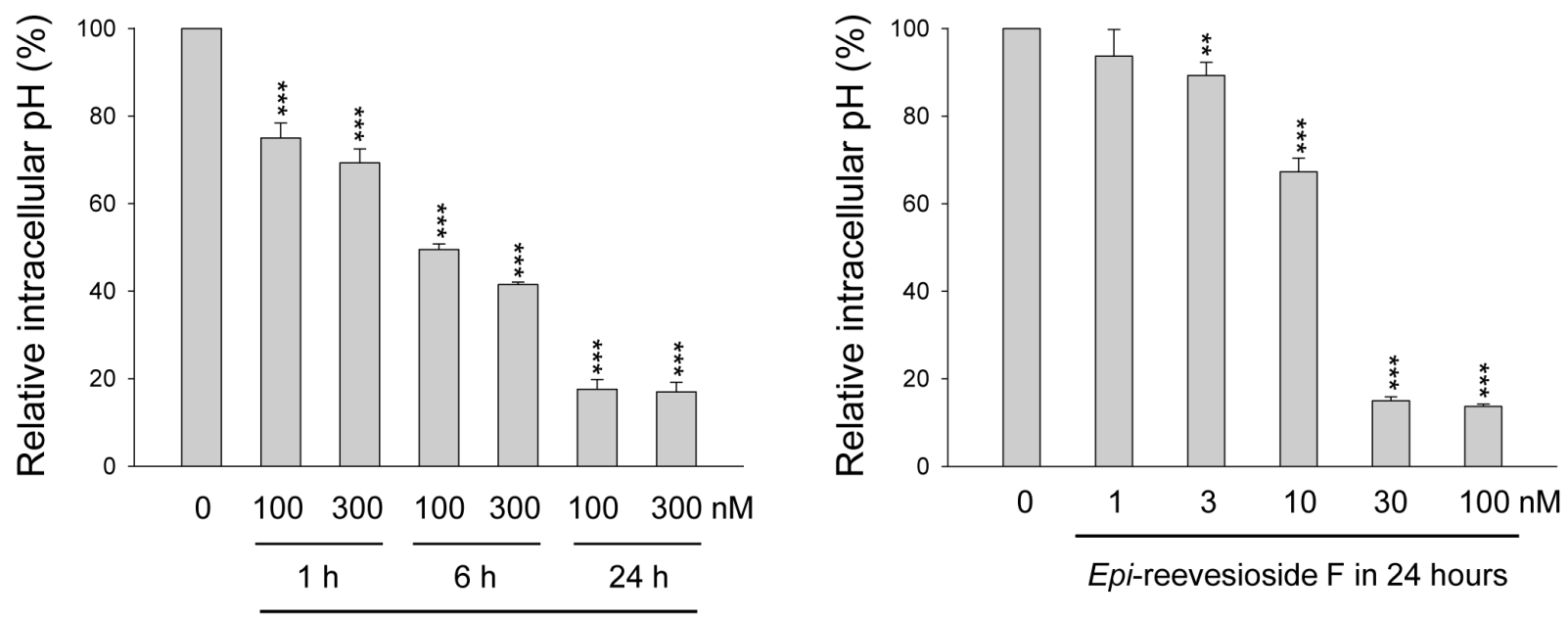

Epi-reevesioside $\mathrm{F}$ in 24 hours

Epi-reevesioside F

B

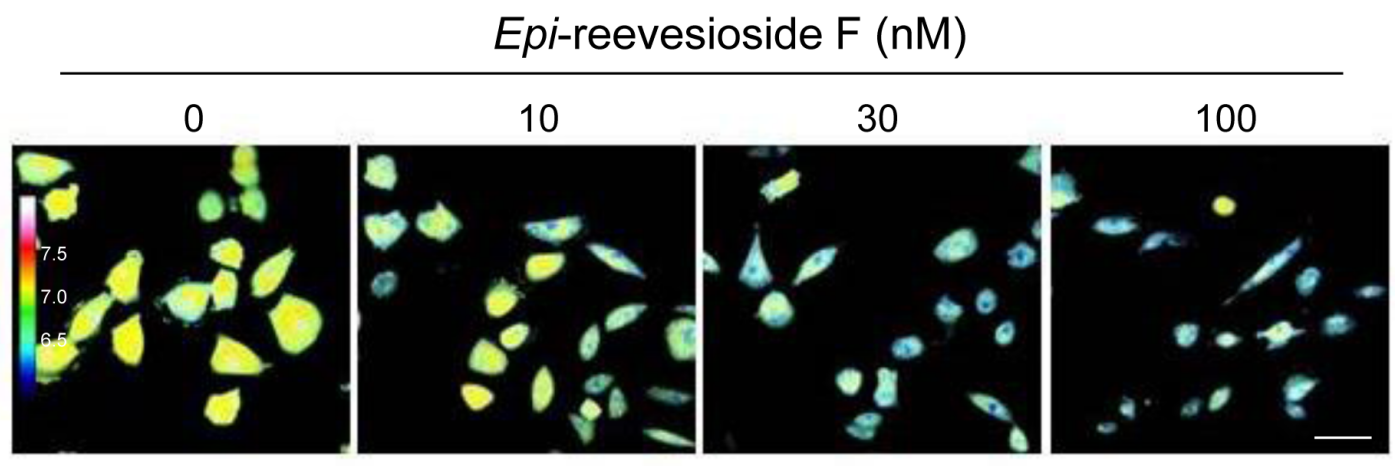

Figure 5: Effect of Epi-reevesioside F on intracellular pH. T98 cells were incubated in the absence or presence of Epi-reevesioside $\mathrm{F}$ for the indicated time (A) or for 24 hours (B). After the treatment, the intracellular $\mathrm{pH}$ was determined using flow cytometric analysis (A), or confocal immunofluorescence microscopic examination (B). Data are expressed as mean \pm SEM of three independent determinations. ${ }^{* *} P$ $<0.01$ and $* * * P<0.001$ compared with the respective control. Bar, $50 \mu \mathrm{m}$. 
Mitochondrial membrane potential $\left(\Delta \Psi_{\mathrm{m}}\right)$ was determined using JC-1 staining. The data demonstrated that Epireevesioside $\mathrm{F}$ induced a concentration-dependent increase of JC-1 monomers (green fluorescence) indicating a loss of $\Delta \Psi_{\mathrm{m}}$ and mitochondrial damage (Figure 6). The effect was significantly inhibited by extracellular potassium supplements (Figure 6).

In cells of neural and non-neural origins, tubulin may form a complex with $\mathrm{Na}^{+} / \mathrm{K}^{+}$-ATPase to regulate enzyme activity. Acetylated tubulin has been identified to be associated with $\mathrm{Na}^{+} / \mathrm{K}^{+}$-ATPase and to block the catalytic activity of the pump [32]. Both Epi-reevesioside $\mathrm{F}$ and ouabain induced a rapid and time-dependent increase of $\alpha$-tubulin acetylation (Figure 7A). Further identification showed that both cardiac glycosides caused a profound decrease of protein expression of $\mathrm{Na}^{+} / \mathrm{K}^{+}$ATPase $\alpha 3$ subunit and phosphorylated Akt (Ser473), and induced activation of caspase- 9 and -3 and cleavage of PARP-1, a caspase-3 substrate (Figure 7B). Bak, a pro- apoptotic Bcl-2 family member, localizes to mitochondria and serves as an apoptotic inducer. After proteolysis, the cleaved Bak reveals a zinc binding site which regulates Bak activity through dimerization [33]. As a result, both Epi-reevesioside $\mathrm{F}$ and ouabain induced a dramatic increase of cleaved Bak formation (Figure 7B). Moreover, flow cytometric analysis showed that Epi-reevesioside F significantly enhanced the exposure of $\mathrm{N}$ terminus of Bak, suggesting an increase of Bak activity (Figure 7C).

\section{DISCUSSION}

Several components have been isolated from the root of Reevesia formosana, including Epi-reevesioside $\mathrm{F}$, reevesioside $\mathrm{A}$, reevesioside $\mathrm{D}$ and reevesioside $\mathrm{F}$. The anti-proliferative activities of these components against glioblastoma cell lines, A172, T98 and U87, were determined. The data demonstrated that all components showed little activities in A172 cells. In contrast, Epi-

\section{Epi-reevesioside $\mathrm{F}(\mathrm{nM})$}
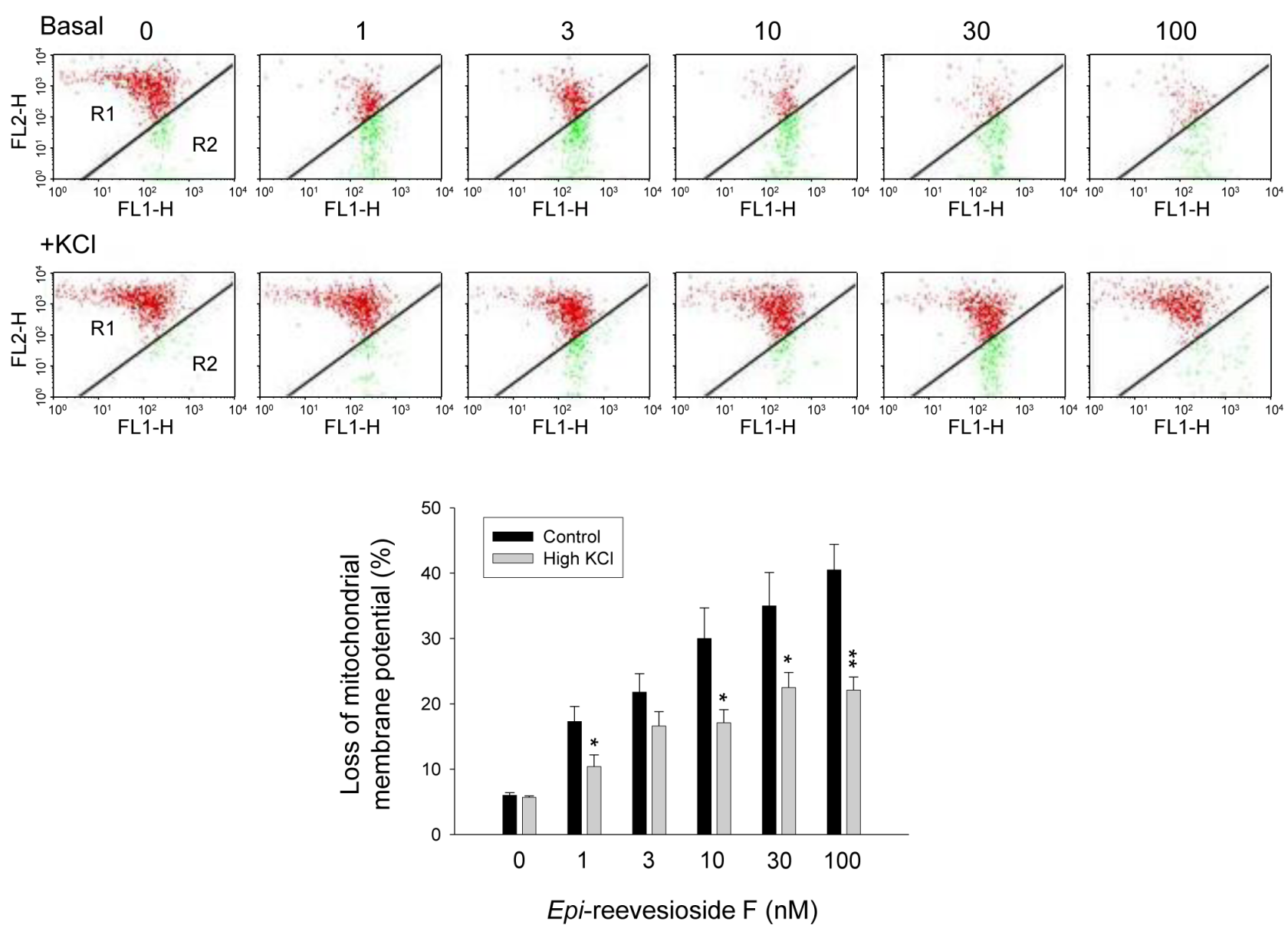

Figure 6: Effect of $\boldsymbol{E p i - r e e v e s i o s i d e ~} \mathbf{F}$ on mitochondrial membrane potential $\left(\Delta \boldsymbol{\Psi}_{\mathbf{m}}\right)$. T98 cells were incubated in the absence or presence of Epi-reevesioside F for 24 hours with or without extracellular potassium supplements $(10.7 \mathrm{mM})$. After the treatment, the cells were incubated with JC-1 for the detection of $\Delta \Psi_{\mathrm{m}}$ using flow cytometric analysis. Data are expressed as mean $\pm \mathrm{SEM}$ of four independent determinations. $* P<0.05$ and $* * P<0.01$ compared with Epi-reevesioside $\mathrm{F}$ alone. 
A

$100105116102166 \quad 145104 \quad 221213 \quad 104 \quad 218214 \quad$ Relative expression (\%)
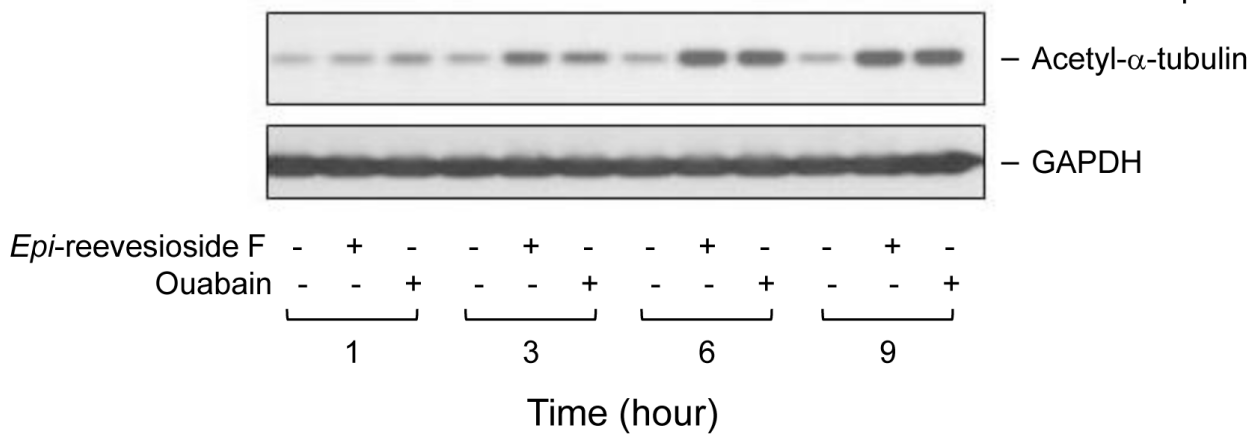

B
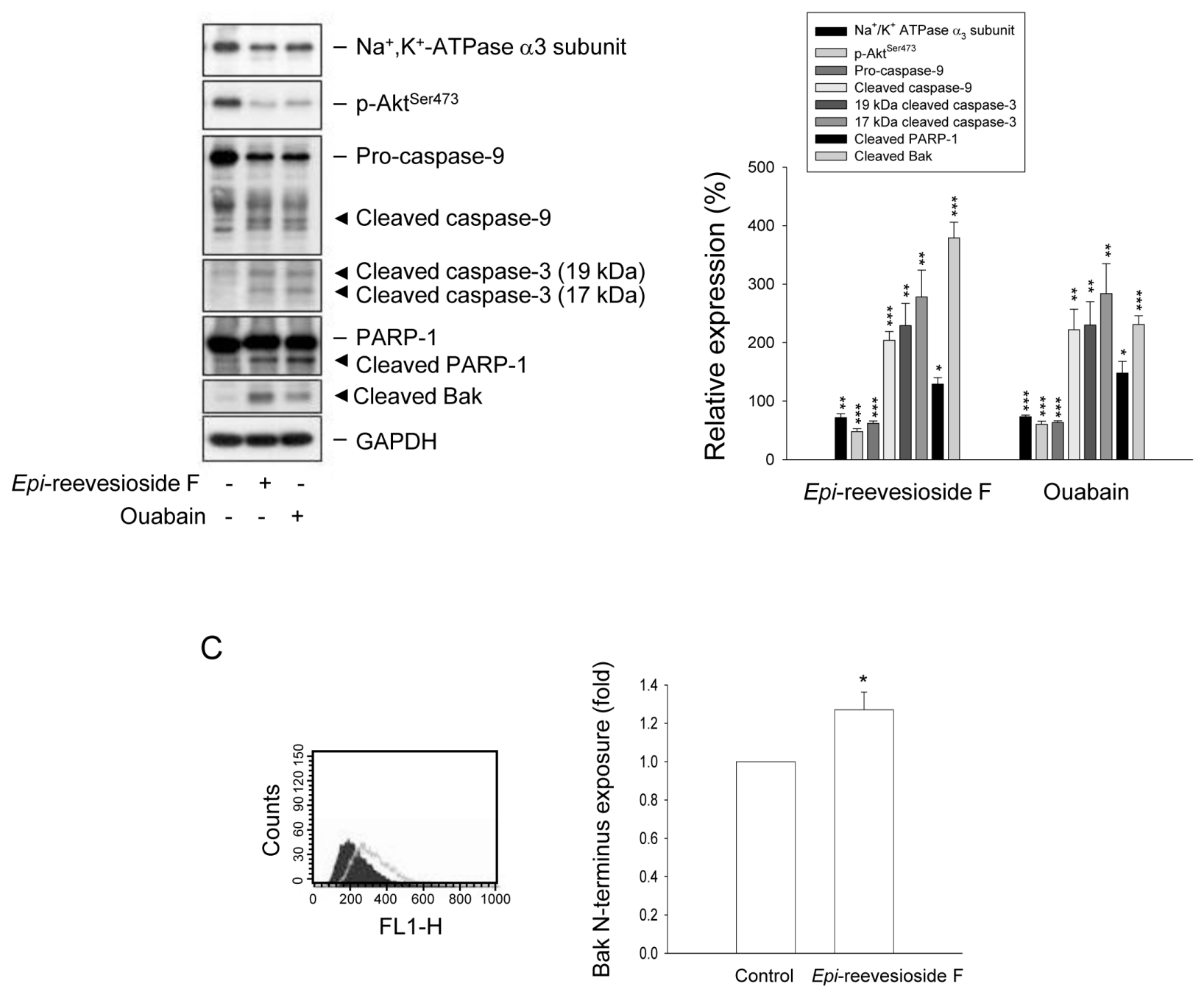

Figure 7: Effect of Epi-reevesioside F and ouabain on several protein expressions. T98 cells were incubated in the absence or presence of Epi-reevesioside F (100 nM) or ouabain $(100 \mathrm{nM})$ for the indicated time $(\mathbf{A})$, or for 48 hours $(\mathbf{B}$ and $\mathbf{C})$. After the treatment, the cells were harvested for the detection of protein expression using Western blot analysis (A and $\mathbf{B})$ or flow cytometric analysis (C). Data are expressed as mean \pm SEM of three independent determinations. ${ }^{*} P<0.05, * * P<0.01$ and $* * * P<0.001$ compared with the respective control. 
reevesioside $\mathrm{F}$, reevesioside $\mathrm{A}$ and reevesioside $\mathrm{F}$ showed potent activities against T98 and U87 cells. Notably, Epi-reevesioside F exhibited higher activities (about two times) than ouabain, while reevesioside $\mathrm{A}$ and reevesioside $\mathrm{F}$ were equipotent to ouabain, in these two cell lines. Reevesioside D was ineffective in all cell lines. Therefore, Epi-reevesioside $\mathrm{F}$ has been selected for anti-glioblastoma study. $\mathrm{Na}^{+} / \mathrm{K}^{+}$-ATPase serves as a multifunctional signal transducer and integrator and is responsible for maintaining resting potential and in regulating cellular volume, contractility, adhesion, inflammation and apoptosis $[11,21,34,35]$. The aberrant expression and activity of $\mathrm{Na}^{+} / \mathrm{K}^{+}$-ATPase have been implicated in the progression of several types of aggressive cancers. $\alpha 1$ and $\alpha 3$ subunits of $\mathrm{Na}^{+} / \mathrm{K}^{+}$-ATPase are frequently overexpressed in colorectal cancer, nonsmall cell lung cancer, melanomas and glioblastomas [3638]. Targeting $\alpha 1$ and $\alpha 3$ subunits has been suggested to trigger both apoptosis- and non-apoptosis related death in cancer cells [11, 21, 36-38] and in cells with multidrugresistant phonotype [39]. It suggests that $\mathrm{Na}^{+} / \mathrm{K}^{+}$-ATPase is a crucial target for development of anticancer agents. Epi-reevesioside $\mathrm{F}$ displayed potent anti-glioblastoma activity and $\mathrm{Na}^{+} / \mathrm{K}^{+}$-ATPase $\alpha 3$ subunit was important in determining this activity. Moreover, Epi-reevesioside F induced profound down-regulation of the $\alpha 3$ subunit. It has been suggested that both endogenous and exogenously applied cardiac glycosides can induce internalization and lysosomal degradation of the ligated $\mathrm{Na}^{+} / \mathrm{K}^{+}$-ATPase and eliminate the pump through a conformational change of the protein itself [40]. The data further supported that $\mathrm{Na}^{+} /$ $\mathrm{K}^{+}$-ATPase $\alpha 3$ subunit served as a primary target of Epireevesioside $\mathrm{F}$. In addition to $\alpha 3$ subunit, the protein levels of other subunits, including $\alpha 1, \alpha 2$ and $\beta 1$, also have been examined. The data demonstrated varied levels of subunit expressions in different cell lines (supplementary figure 5). Notably, A172 cells expressed high levels of $\alpha 1, \alpha 2$ and $\beta 1$ subunits. However, Epi-reevesioside F did not show activity on the inhibition of A172 proliferation. Similar low effect but high expression of $\alpha 1$ subunit expression was obtained in $\mathrm{H} 9 \mathrm{c} 2$ cells to Epi-reevesioside F action. Overall, Epi-reevesioside F-induced anti-proliferative effects in these cell lines were highly correlated to the expression of $\alpha 3$ subunit but not $\alpha 1$ or $\alpha 2$ subunit.

Microtubules are highly dynamic polymers involved in a variety of cellular processes, such as cell division, differentiation and signal transduction. $\alpha$-tubulin and $\beta$-tubulin are two major members of tubulin superfamily making up microtubule. Tubulin acetylation, a posttranslational modification, may help recruit molecular chaperons and regulate client proteins involved in cell proliferation and apoptosis [41]. Tubulin can also form a complex with $\mathrm{Na}^{+} / \mathrm{K}^{+}$-ATPase to orchestrate the pump activity. However, acetylated tubulin can bind to $\mathrm{Na}^{+} / \mathrm{K}^{+}-$ ATPase and blunt its catalytic activity [32]. Moreover, tubulin acetylation is correlated to cell apoptosis. A number of small molecule inhibitors in inhibiting histone deacetylase 6 have been reported to induce tubulin acetylation and to display anti-proliferative and apoptotic activities [42]. Epi-reevesioside $\mathrm{F}$ induced tubulin acetylation which correlated with the inhibition of $\mathrm{Na}^{+} /$ $\mathrm{K}^{+}$-ATPase activity and could contribute to the antiglioblastoma activity.

Epi-reevesioside $\mathrm{F}$ induced cell cycle arrest at $\mathrm{S}$ and $\mathrm{G} 2 / \mathrm{M}$ phases in T98 cells and that at $\mathrm{G} 2 / \mathrm{M}$ phase in $\mathrm{U} 87$ cells. It has been reported that proscillaridin A, a cardiac glycoside inhibitor of $\mathrm{Na}^{+} / \mathrm{K}^{+}$-ATPase, induced $\mathrm{G} 2 / \mathrm{M}$ arrest in glioblastoma cell lines [43]. Bufotalin, a cardiac glycoside secreted by a number of toad species, also induced $\mathrm{G} 2 / \mathrm{M}$ arrest through down-regulation of several cell cycle regulators including aurora $\mathrm{A}, \mathrm{Cdc} 25$, cyclin-dependent kinase 1 and cyclin A, and up-regulation of p53 and p21 in hepatocellular carcinoma HepG2 cells [4]. After further examination, Epi-reevesioside F neither modified protein expressions of cell cycle regulators (data not shown) nor induced DNA damage during the initiation of cellular stress in glioblastoma cells. It is noteworthy that several types of cells exposed to hyperosmolality undergo growth arrest at $\mathrm{S}$ and $\mathrm{G} 2 / \mathrm{M}$ phases of cell cycle $[24,25]$. A number of proteins and kinases are involved in hyperosmotic cell cycle delay, including GADD45, GADD153, extracellular signal-regulated kinases 1 and 2, c-Jun N-terminal kinase and p38 mitogen-activated protein kinase $[25,44]$. Epi-reevesioside F resulted in a significant increase of intracellular $\mathrm{Na}^{+}$concentrations and a decrease of cell size indicating the induction of hyperosmotic stress. It could explain the cell cycle arrest and inhibition of cell proliferation in glioblastoma cells. Notably, phosphoinositide 3-kinase (PI3-kinase)/Akt pathway is crucial in determining the cell fate under hyperosmotic stress. The activation of PI3-kinase/Akt has been suggested to prevent mild hyperosmolalityinduced apoptotic stress in Madin-Darby canine kidney cells [45]. On the contrary, the hyperosmolar stress can down-regulate PI3-kinase activity and induce apoptosis in several types of cells [46]. The present work showed that Epi-reevesioside $\mathrm{F}$ caused the decrease of Akt phosphorylation on Ser-473, indicating an inhibition of Akt activity. The data reveal that inhibition of PI3-kinase/ Akt pathway may confer Epi-reevesioside F-induced antiglioblastoma activity in a hyperosmolar stress.

Several lines of evidence showing that hyperosmotic stress leads to cytosolic acidification followed by mitochondrial dysfunction and activation of apoptotic pathway. During the suicidal program, $\mathrm{Ca}^{2+}$ entry through $\mathrm{Ca}^{2+}$-permeable cation channels or exchangers may decrease mitochondrial integrity, activating several proteinases and inducing cell shrinkage [47]. The data demonstrated that Epi-reevesioside $\mathrm{F}$ induced a rapid and significant increase of intracellular $\mathrm{Na}^{+}$concentrations and cytosolic acidification followed by the loss of mitochondrial membrane potential which was significantly 
rescued by extracellular potassium supplements. However, Epi-reevesioside $\mathrm{F}$ did not modify the intracellular $\mathrm{Ca}^{2+}$ concentrations. The data indicate that the ion transport and cytosolic acidification, but not $\mathrm{Ca}^{2+}$ mobilization, contribute to mitochondria-involved apoptotic cell death in glioblastoma cells. Several anticancer approaches have been proposed to induce intracellular acidification. The rationale is based on the consideration that under conditions of cytosolic acidification, the cells are susceptible to DNA degradation by acid-activated deoxyribonuclease (DNase) although $\mathrm{Ca}^{2+} / \mathrm{Mg}^{2+}-$ dependent endonucleases dominate DNA digestion in several apoptotic conditions [48]. Furthermore, it has been suggested that DNA digestion in cell apoptosis frequently is not related to alterations in intracellular $\mathrm{Ca}^{2+}$ levels but correlates with intracellular acidification [49]. A variety of cancer chemotherapeutic drugs have been discovered to induce apoptosis on the basis of intracellular acidification and activation of acid-activated DNase II [49]. These studies reveal that targeting the mechanisms of intracellular $\mathrm{pH}$ regulation can be a potential anticancer strategy. To this end, Epi-reevesioside F which inhibits $\mathrm{Na}^{+} / \mathrm{K}^{+}$-ATPase, leading to changes in ion transport and intracellular acidification may be a potential candidate for further development.

Bcl-2 family proteins including pro-apoptotic (e.g., Bax, Bak, Bad and Bid) and anti-apoptotic members (e.g., Bcl-2, Bcl-xL and Mcl-1) govern mitochondrial outer membrane permeability. Many $\mathrm{Bcl}-2$ family proteins bind themselves and each other to form homodimers or heterodimers. Increasing lines of evidence suggest that changes in cytosolic $\mathrm{pH}$ may regulate the functions of Bcl-2 family members [50]. Dimerization of Bcl-2 family proteins can be promoted under lower $\mathrm{pH}$ through a decreased rate of dimer dissociation [51]. Moreover, mitochondrial proton transporters and proton circuit can be affected by variations in cytosolic $\mathrm{pH}$ [52]. Of note, apoptosis induced by cytosolic acidification can be either caspase-dependent or caspase-independent $[30,50]$. In this regard, Epi-reevesioside F induced a significant loss of mitochondrial membrane potential and a dramatic increase of cleaved Bak formation and its exposure of $\mathrm{N}$ terminus suggesting a profound increase of Bak activity [33]. In addition, caspase-dependent apoptosis was activated to Epi-reevesioside $\mathrm{F}$ action. Bak is constitutively expressed in mitochondrial outer membrane. Bak and Bax form mitochondrial apoptosis-induced channel and, furthermore, Bak interacts and enhances the opening of mitochondrial voltage-dependent anion channel, making mitochondrial outer membrane permeable to pro-apoptotic proteins, such as cytochrome $c$ and Smac/DIABLO [53, 54]. It is essential in coordinating apoptosis induced by various cancer chemotherapeutic drugs in a variety of cancers, including temozolomide in the treatment of glioblastoma multiforme [55]. The data suggest that Bak activation may enhance Epi-reevesioside F-induced anti- glioblastoma activity through mitochondrial apoptosis pathway.

Taken together, the data suggest that Epireevesioside $\mathrm{F}$ can potently inhibit $\mathrm{Na}^{+} / \mathrm{K}^{+}$-ATPase, leading to overload of intracellular $\mathrm{Na}^{+}$, changes in ion transport and cytosolic acidification which in turn result in Bak activation and a loss of mitochondrial membrane potential. The PI3-kinase/Akt pathway is inhibited and caspase-dependent apoptosis is ultimately triggered in Epireevesioside F-treated glioblastoma cells. The data suggest that Epi-reevesioside F can be a potential candidate for anti-glioblastoma development.

\section{MATERIALS AND METHODS}

\section{Materials}

DMEM and fetal bovine serum (FBS) were obtained from GIBCO/BRL Life Technologies (Grand Island, NY). Antibodies to caspase-3, PARP-1, $\alpha$-tubulin, and antimouse and anti-rabbit IgGs were obtained from Santa Cruz Biotechnology, Inc. (Santa Cruz, CA). Antibodies to acetyl- $\alpha$-tubulin ${ }^{\mathrm{Lys} 40}, \mathrm{p}-\mathrm{Akt}^{\mathrm{Ser} 473}$ and $\mathrm{p}-\mathrm{Akt}^{\mathrm{Thr308}}$ were from Cell Signaling Technologies (Boston, MA). Ouabain, propidium iodide (PI), sulforhodamine B, RNase, trichloroacetic acid (TCA), Triton X-100, phenylmethylsulfonyl fluoride, leupeptin, aprotinin, sodium fluoride, sodium orthovanadate and proteinase $\mathrm{K}$ were obtained from Sigma-Aldrich (St. Louis, MO). Fluo-3/AM, JC-1 and carboxyfluorescein succinimidyl ester (CFSE) were from Molecular Probes Inc. (Eugene, OR, USA). Epi-reevesioside F was isolated from the root of Reevesia formosana. Purification and identification of Epi-reevesioside F were published elsewhere [20].

\section{Cell lines and cell culture}

A172, T98 and U87, three human cell lines derived from glioblastoma, were from American Type Culture Collection (Rockville, MD). Cells were cultured in DMEM supplemented with $10 \%$ heat-inactive FBS $(v / v)$, penicillin (100 units $/ \mathrm{ml})$ and streptomycin $(100 \mu \mathrm{g} / \mathrm{ml})$. Cultures were maintained in a $37^{\circ} \mathrm{C}$ incubator with $5 \%$ $\mathrm{CO}_{2}$.

\section{Sulforhodamine B assay}

Cells were seeded in 96-well plates in medium with 10\% FBS. After 24 hours, cells were fixed with $10 \%$ TCA to represent cell population at the time of compound addition $\left(\mathrm{T}_{0}\right)$. After additional incubation of $0.1 \%$ dimethylsulfoxide (DMSO) or the indicated compound for 48 hours in A172 and T98 cells (doubling 
time between 24 and 30 hours) or 72 hours in U87 cells (doubling time, 60 hours), cells were fixed with $10 \%$ TCA and sulforhodamine $\mathrm{B}$ at $0.4 \%(\mathrm{w} / \mathrm{v})$ in $1 \%$ acetic acid was added to stain cells. Unbound sulforhodamine B was washed out by $1 \%$ acetic acid. Sulforhodamine B bound cells were solubilized with $10 \mathrm{mM}$ Trizma base. The absorbance was read at a wavelength of $515 \mathrm{~nm}$. Using the following absorbance measurements, such as time zero $\left(\mathrm{T}_{0}\right)$, control growth $(\mathrm{C})$, and cell growth in the presence of the indicated compound (Tx), the percentage growth was calculated at each of the compound concentrations levels. Percentage growth inhibition was calculated as: [1- (Tx$\left.\left.\mathrm{T}_{0}\right) /\left(\mathrm{C}-\mathrm{T}_{0}\right)\right] \times 100 \%$. Growth inhibition of $50 \%\left(\mathrm{IC}_{50}\right)$ is determined at the compound concentration which results in $50 \%$ reduction of total protein increase in control cells during the compound incubation.

\section{Cell proliferation assay by CFSE labeling}

CFSE was dissolved in DMSO to constitute a storage solution of $10 \mathrm{mM}$ and kept at $-80^{\circ} \mathrm{C}$ until use. The cells were adjusted to a density of $10^{6}$ cells $/ \mathrm{ml}$ and were treated with CFSE at a final concentration of $10 \mu \mathrm{M}$. After incubation at $37^{\circ} \mathrm{C}$ for 10 minutes, DMEM with $10 \%$ FCS was added. Tubes were placed in ice for 5 minutes and then washed. After centrifugation, the cells were seeded in DMEM with $10 \% \mathrm{FCS}$ for the indicated times at $37^{\circ} \mathrm{C}$ in $5 \% \mathrm{CO}_{2} / 95 \%$ air. After the treatment, the fluorescence intensity was determined by flow cytometric analysis (Becton Dickinson, Mountain View, CA).

\section{Flow cytometric assay of PI staining}

After the exposure to the indicated agent, cells were harvested by trypsinization, fixed with $70 \%(v / v)$ alcohol at $4^{\circ} \mathrm{C}$ for 30 minutes and washed with PBS. The cells were centrifuged and resuspended with $0.5 \mathrm{ml}$ PI solution containing Triton X-100 $(0.1 \%, v / v)$, RNase $(100 \mu \mathrm{g} / \mathrm{ml})$ and PI $(80 \mu \mathrm{g} / \mathrm{ml})$. DNA content was analyzed with the FACScan and CellQuest software (Becton Dickinson, Mountain View, CA).

\section{Measurement of intracellular $\mathrm{Ca}^{2+}$ concentrations}

Cells were pre-incubated with fluo-3/AM (2.5 $\mu \mathrm{M})$ for 30 minutes. The cells were washed twice and incubated in fresh medium. Vehicle (0.1\% DMSO), Epi-reevesioside $\mathrm{F}$ or ouabain was added to the cells for the indicated times. The intracellular $\mathrm{Ca}^{2+}$ concentrations were determined by flow cytometric analysis (Becton Dickinson, Mountain View, CA).

\section{Measurement of $\Delta \Psi_{\mathrm{m}}$}

JC-1, a mitochondrial dye staining mitochondria in living cells in a membrane potential-dependent fashion, was used to determine $\Delta \Psi_{\mathrm{m}}$. Cells were treated with or without Epi-reevesioside F. Thirty minutes before the termination of incubation, the cells were incubated with JC-1 (final concentration of $2 \mu \mathrm{M}$ ) at $37^{\circ} \mathrm{C}$ for 30 minutes. The cells were finally harvested and the accumulation of JC-1 was determined using flow cytometric analysis (Becton Dickinson, Mountain View, CA).

\section{Measurement of intracellular $\mathrm{Na}^{+}$concentrations}

After the treatment, the cells were incubated with CoroNa Green $(1 \mu \mathrm{M})$ for 45 minutes. The cells were washed twice and suspended in PBS. The intracellular $\mathrm{Na}^{+}$concentrations were determined by flow cytometric analysis (Becton Dickinson, Mountain View, CA).

\section{Detection of intracellular acidification}

After the treatment, the cells were incubated with seminaphtharhodafluor-1 $(1 \mu \mathrm{M})$ for 45 minutes. The cells were washed twice and suspended in PBS. The fluorescence emission in channels FL2 and FL3 was analyzed with a flow cytometer. During the elaboration of the data, a ratio of the fluorescence emissions and the mean fluorescence ratio were calculated. Furthermore, isolated T98 cells were recorded in an open chamber slide and were analyzed by a confocal laser microscopic system (Leica TCS SP2).

\section{Western blotting}

After the treatment, the cells were harvested by trypsinization, centrifuged and lysed in $0.1 \mathrm{ml}$ of lysis buffer $(10 \mathrm{mM}$ Tris- $\mathrm{HCl} \mathrm{pH} 7.4,150 \mathrm{mM} \mathrm{NaCl}, 1 \mathrm{mM}$ EGTA, $1 \%$ Triton X-100, 1 mM phenylmethylsulfonyl fluoride, $10 \mu \mathrm{g} / \mathrm{ml}$ leupeptin, $10 \mu \mathrm{g} / \mathrm{ml}$ aprotinin, $50 \mathrm{mM}$ sodium fluoride and $100 \mu \mathrm{M}$ sodium orthovanadate). For Western blot analysis, $40 \mu \mathrm{g}$ proteins were separated by electrophoresis in a $12 \%$ polyacrylamide gel and transferred to a PVDF membrane. After one hour incubation at room temperature in $\mathrm{PBS} / 5 \%$ non-fat milk, the membrane was washed with $\mathrm{PBS} / 0.1 \%$ Tween 20 for another 1 hour and overnight incubated with the indicated antibody at $4^{\circ} \mathrm{C}$. After three washings with PBS/0.1\% Tween 20, the anti-mouse or anti-rabbit IgG (dilute 1:4000) was applied to the membranes for 1 hour at room temperature. The membranes were washed with PBS/0.1\% Tween 20 for 1 hour and the detection of signal was performed with an enhanced chemiluminescence detection kit (Amersham, Buckinghamshire, UK). 


\section{Flow cytometric assay of exposed $\mathrm{N}$ terminus of Bak}

After the treatment, the cells were harvested by trypsinization, fixed with $4 \%(\mathrm{v} / \mathrm{v})$ paraformaldehyde $(\mathrm{pH}=7.4)$ at $4^{\circ} \mathrm{C}$ for 5 minutes and washed with PBS. After centrifugation, cells were permeabilized with $0.01 \%$ saponin/PBS and incubated with anti-Bak antibody (N terminus) or IgG for 1 hour at $4^{\circ} \mathrm{C}$. The cells were then washed and incubated with FITC-labeled anti-mouse secondary antibody for another 1 hour at $4^{\circ} \mathrm{C}$. Cells were washed and re-suspended in PBS for the flow cytometric analysis (Becton Dickinson, Mountain View, CA).

\section{Data analysis}

Data are presented as the mean \pm SEM for the indicated number of separate experiments. Statistical analysis of data for multiple groups is performed with one-way analysis of variance (ANOVA). Student's $t$-test is applied for comparison of two groups. $P$-values less than 0.05 are statistically considered significant.

\section{ACKNOWLEDGMENTS}

We acknowledge the support provided by the Ministry of Science and Technology in Taiwan (MOST 103-2320-B-002-009-MY3 and MOST 101-2320-B-002018-MY3). The support by the Center for Innovative Therapeutics Discovery at National Taiwan University is also acknowledged.

\section{CONFLICTS OF INTEREST}

All authors declared no conflict of interest.

\section{REFERENCES}

1. Ottolia M, Torres N, Bridge JH, Philipson KD, Goldhaber JI. Na/Ca exchange and contraction of the heart. J Mol Cell Cardiol. 2013; 61: 28-33.

2. Webster KA. Mitochondrial membrane permeabilization and cell death during myocardial infarction: roles of calcium and reactive oxygen species. Future Cardiol. 2012; 8: 863-884.

3. Winnicka K, Bielawski K, Bielawska A, Surazyński A. Antiproliferative activity of derivatives of ouabain, digoxin and proscillaridin A in human MCF-7 and MDA-MB-231 breast cancer cells. Biol Pharm Bull. 2008; 31: 1131-1140.

4. Zhang DM, Liu JS, Tang MK, Yiu A, Cao HH, Jiang L, Chan JY, Tian HY, Fung KP, Ye WC. Bufotalin from Venenum Bufonis inhibits growth of multidrug resistant HepG2 cells through G2/M cell cycle arrest and apoptosis. Eur J Pharmacol. 2012; 692: 19-28.
5. Lefranc F, Pouleau HB, Rynkowski M, De Witte O. Voltage-dependent $\mathrm{K}+$ channels as oncotargets in malignant gliomas. Oncotarget. 2012; 3: 516-517.

6. Newman RA, Yang P, Hittelman WN, Lu T, Ho DH, Ni D, Chan D, Vijjeswarapu M, Cartwright C, Dixon S, Felix E, Addington C. Oleandrin-mediated oxidative stress in human melanoma cells. J Exp Ther Oncol. 2006; 5: 167-181.

7. Manna SK, Sah NK, Newman RA, Cisneros A, Aggarwal BB. Oleandrin suppresses activation of nuclear transcription factor-kappaB, activator protein-1, and c-Jun NH2-terminal kinase. Cancer Res. 2000; 60: 3838-3847.

8. Raghavendra PB, Sreenivasan Y, Ramesh GT, Manna SK. Cardiac glycoside induces cell death via FasL by activating calcineurin and NF-AT, but apoptosis initially proceeds through activation of caspases. Apoptosis. 2007; 12: 307318.

9. Trenti A, Grumati P, Cusinato F, Orso G, Bonaldo P, Trevisi L. Cardiac glycoside ouabain induces autophagic cell death in non-small cell lung cancer cells via a JNKdependent decrease of Bcl-2. Biochem Pharmacol. 2014; 89: 197-209.

10. Mijatovic T, De Nève N, Gailly P, Mathieu V, Haibe-Kains B, Bontempi G, Lapeira J, Decaestecker C, Facchini V, Kiss R. Nucleolus and c-Myc: potential targets of cardenolidemediated antitumor activity. Mol Cancer Ther. 2008; 7: 1285-1296.

11. Leu WJ, Chang HS, Chan SH, Hsu JL, Yu CC, Hsu LC, Chen IS, Guh JH. Reevesioside A, a cardenolide glycoside, induces anticancer activity against human hormonerefractory prostate cancers through suppression of c-myc expression and induction of G1 arrest of the cell cycle. PLoS One. 2014; 9: e87323.

12. Harguindey S, Orive G, Luis Pedraz J, Paradiso A, Reshkin SJ. The role of $\mathrm{pH}$ dynamics and the $\mathrm{Na}+\mathrm{H}+$ antiporter in the etiopathogenesis and treatment of cancer. Two faces of the same coin-one single nature. Biochim Biophys Acta. 2005; 1756: 1-24.

13. Xu B, Jin X, Min L, Li Q, Deng L, Wu H, Lin G, Chen L, Zhang H, Li C, Wang L, Zhu J, Wang W, Chu F, Shen J, Li $\mathrm{H}$, Mao J. Chloride channel-3 promotes tumor metastasis by regulating membrane ruffling and is associated with poor survival. Oncotarget. 2015; 6: 2434-2450.

14. Cardone RA, Casavola V, Reshkin SJ. The role of disturbed $\mathrm{pH}$ dynamics and the $\mathrm{Na}+\mathrm{H}+$ exchanger in metastasis. Nat Rev Cancer. 2005; 5: 786-7895.

15. Lauritzen G, Jensen MB, Boedtkjer E, Dybboe R, Aalkjaer C, Nylandsted J, Pedersen SF. NBCn1 and NHE1 expression and activity in DeltaNErbB2 receptor-expressing MCF-7 breast cancer cells: Contributions to $\mathrm{pHi}$ regulation and chemotherapy resistance. Exp Cell Res. 2010; 316: 2538-2553.

16. Murakami T, Shibuya I, Ise T, Zhe-Sheng Ch, Akiyama S, Nakagawa M., Izumi H, Nakamura T, Matsuo K, Yamada $\mathrm{Y}$ and Kohno K: Elevated expression of vacuolar proton 
pump genes and cellular $\mathrm{pH}$ in cisplatin resistance. Int $\mathbf{J}$ Cancer. 2001; 93: 869-874.

17. Harguindey S, Arranz JL, Wahl ML, Orive G, Reshkin SJ. Proton transport inhibitors as potentially selective anticancer drugs. Anticancer Res. 2009; 29: 2127-2136.

18. Matsuyama S, Llopis J, Deveraux QL, Tsien RY, Reed JC. Changes in intramitochondrial and cytosolic $\mathrm{pH}$ : early events that modulate caspase activation during apoptosis. Nature Cell Biol. 2000; 2: 318-325.

19. Reshkin SJ, Bellizzi A, Cardone RA, Tommasino M, Casavola V, Paradiso A. Paclitaxel induces apoptosis via protein kinase A- and p38 mitogen-activated proteindependent inhibition of the $\mathrm{Na}^{+} / \mathrm{H}^{+}$exchanger (NHE) isoform 1 in human breast cancer cells. Clin Cancer Res. 2003; 9: 2366-2373.

20. Chang HS, Chiang MY, Hsu HY, Yang CW, Lin CH, Lee SJ, Chen IS. Cytotoxic cardenolide glycosides from the root of Reevesia formosana. Phytochemistry. 2013; 87: 86-95.

21. Chan SH, Leu WJ, Hsu LC, Chang HS, Hwang TL, Chen IS, Chen CS, Guh JH. Reevesioside F induces potent and efficient anti-proliferative and apoptotic activities through $\mathrm{Na}^{+} / \mathrm{K}^{+}$-ATPase $\alpha 3$ subunit-involved mitochondrial stress and amplification of caspase cascades. Biochem Pharmacol. 2013; 86: 1564-1575.

22. Katz A, Lifshitz Y, Bab-Dinitz E, Kapri-Pardes E, Goldshleger R, Tal DM, Karlish SJ. Selectivity of digitalis glycosides for isoforms of human Na,K-ATPase. J Biol Chem. 2010; 285: 19582-19592.

23. Chen T, Stephens PA, Middleton FK, Curtin NJ. Targeting the $\mathrm{S}$ and G2 checkpoint to treat cancer. Drug Discov Today. 2012; 17: 194-202

24. Arsenijevic T, Vujovic A, Libert F, Op de Beeck A, Hébrant A, Janssens S, Grégoire F, Lefort A, Bolaky N, Perret J, Caspers L, Willermain F, Delporte C. Hyperosmotic stress induces cell cycle arrest in retinal pigmented epithelial cells. Cell Death Dis. 2013; 4: e662.

25. Mak S, Kültz D. Gadd45 proteins induce G2/M arrest and modulate apoptosis in kidney cells exposed to hyperosmotic stress. J Biol Chem. 2004; 279: 39075-39084.

26. Lucas CA, Gillies RJ, Olson JE, Giuliano KA, Martinez $\mathrm{R}$, Sneider JM. Intracellular acidification inhibits the proliferative response in BALB/c-3T3 cells. J Cell Physiol. 1988; 136: 161-167.

27. McCarty MF, Whitaker J. Manipulating tumor acidification as a cancer treatment strategy. Altern Med Rev. 2010; 15: 264-272.

28. Counillon L, Pouysségur J. The expanding family of eucaryotic $\mathrm{Na}^{+} / \mathrm{H}^{+}$exchangers. J Biol Chem. 2000; 275: 1-4.

29. Lehoux S, Abe Ji, Florian JA, Berk BC. 14-3-3 Binding to $\mathrm{Na}+\mathrm{H}+$ exchanger isoform- 1 is associated with serumdependent activation of $\mathrm{Na}^{+} / \mathrm{H}^{+}$exchange. J Biol Chem. 2001; 276: 15794-15800.

30. Lagadic-Gossmann D, Huc L, Lecureur V. Alterations of intracellular $\mathrm{pH}$ homeostasis in apoptosis: origins and roles.
Cell Death Differ. 2004; 11: 953-961.

31. Counis MF, Torriglia A. Acid DNases and their interest among apoptotic endonucleases. Biochimie. 2006; 88: 1851-1858.

32. Santander VS, Bisig CG, Purro SA, Casale CH, Arce CA, Barra HS. Tubulin must be acetylated in order to form a complex with membrane $\mathrm{Na}^{+}, \mathrm{K}^{+}$-ATPase and to inhibit its enzyme activity. Mol Cell Biochem. 2006; 291: 167-174.

33. Moldoveanu T, Liu Q, Tocilj A, Watson M, Shore G, Gehring K. The X-ray structure of a Bak homodimer reveals an inhibitory zinc binding site. Mol Cell. 2006; 24: 677-688.

34. Forrest MD, Wall MJ, Press DA, Feng J. The sodiumpotassium pump controls the intrinsic firing of the cerebellar Purkinje neuron. PLoS One 2012; 7: e51169.

35. Paul D, Soignier RD, Minor L, Tau H, Songu-Mize E, Gould HJ 3rd. Regulation and pharmacological blockade of sodium-potassium ATPase: a novel pathway to neuropathy. J Neurol Sci. 2014; 340: 139-143.

36. Suñol M, Cusi V, Cruz O, Kiss R, Lefranc F. Immunohistochemical analyses of alpha1 and alpha3 $\mathrm{Na}+$ / $\mathrm{K}+$-ATPase subunit expression in medulloblastomas. Anticancer Res. 2011; 31: 953-958.

37. Lefranc F, Mijatovic T, Kondo Y, Sauvage S, Roland I, Debeir O, Krstic D, Vasic V, Gailly P, Kondo S, Blanco G, Kiss R. Targeting the alpha-1 subunit of the sodium pump to combat glioblastoma cells. Neurosurgery. 2008; 62: 211221.

38. Sakai H, Suzuki T, Maeda M, Takahashi Y, Horikawa N, Minamura T, Tsukada K, Takeguchi N. Up-regulation of $\mathrm{Na}^{+}, \mathrm{K}^{+}$-ATPase alpha3-isoform and down-regulation of the alpha1-isoform in human colorectal cancer. FEBS Lett. 2004; 563: 151-154.

39. Mijatovic T, Jungwirth U, Heffeter $\mathrm{P}$, Hoda MA, Dornetshuber R, Kiss R, Berger W. The $\mathrm{Na}^{+} / \mathrm{K}^{+}$-ATPase is the Achilles heel of multi-drug-resistant cancer cells. Cancer Lett. 2009; 282: 30-34.

40. Cherniavsky-Lev M, Golani O, Karlish SJ, Garty H. Ouabain-induced internalization and lysosomal degradation of the $\mathrm{Na}^{+} / \mathrm{K}^{+}$-ATPase. J Biol Chem. 2014; 289: 1049-1059.

41. Giustiniani J, Daire V, Cantaloube I, Durand G, Poüs C, Perdiz D, Baillet A. Tubulin acetylation favors Hsp90 recruitment to microtubules and stimulates the signaling function of the Hsp90 clients Akt/PKB and p53. Cell Signal. 2009; 21: 529-539.

42. Aldana-Masangkay GI, Rodriguez-Gonzalez A, Lin T, Ikeda AK, Hsieh YT, Kim YM, Lomenick B, Okemoto K, Landaw EM, Wang D, Mazitschek R, Bradner JE, Sakamoto KM. Tubacin suppresses proliferation and induces apoptosis of acute lymphoblastic leukemia cells. Leuk Lymphoma. 2011; 52: 1544-1555.

43. Denicolaï E, Baeza-Kallee N, Tchoghandjian A, Carré M, Colin C, Jiglaire CJ, Mercurio S, Beclin C, FigarellaBranger D. Proscillaridin A is cytotoxic for glioblastoma 
cell lines and controls tumor xenograft growth in vivo. Oncotarget 2014; 5: 10934-10948.

44. Kültz D, Madhany S, Burg MB. Hyperosmolality causes growth arrest of murine kidney cells. Induction of GADD45 and GADD153 by osmosensing via stress-activated protein kinase 2. J Biol Chem. 1998; 273: 13645-13651.

45. Terada $Y$, Inoshita S, Hanada S, Shimamura H, Kuwahara M, Ogawa W, Kasuga M, Sasaki S, Marumo F. Hyperosmolality activates Akt and regulates apoptosis in renal tubular cells. Kidney Int. 2001; 60: 553-567.

46. Zundel W, Giaccia A. Inhibition of the anti-apoptotic PI(3) K/Akt/Bad pathway by stress. Genes Dev. 1998; 12: 19411946.

47. Lang F, Hoffmann EK. Role of ion transport in control of apoptotic cell death. Compr Physiol. 2012; 2: 2037-2061.

48. Yakovlev AG, Wang G, Stoica BA, Boulares HA, Spoonde AY, Yoshihara K, Smulson ME. A role of the $\mathrm{Ca}^{2+} / \mathrm{Mg}^{2+}-$ dependent endonuclease in apoptosis and its inhibition by Poly(ADP-ribose) polymerase. J Biol Chem. 2000; 275: 21302-21308.

49. Barry MA, Reynolds JE, Eastman A. Etoposide-induced apoptosis in human HL-60 cells is associated with intracellular acidification. Cancer Res. 1993; 53(10 Suppl): 2349-2357.

50. Matsuyama S, Reed JC. Mitochondria-dependent apoptosis and cellular $\mathrm{pH}$ regulation. Cell death Differ. 2000; 7: 11551165.

51. Xie Z, Schendel S, Matsuyama S, Reed JC. Acidic $\mathrm{pH}$ promotes dimerization of $\mathrm{Bcl}-2$ family proteins. Biochemistry. 1998; 37: 6410-6418.

52. Santo-Domingo J, Demaurex N. Perspectives on: SGP symposium on mitochondrial physiology and medicine: the renaissance of mitochondrial pH. J Gen Physiol. 2012; 139: 415-423.

53. Dejean LM, Martinez-Caballero S, Guo L, Hughes C, Teijido O, Ducret T, Ichas F, Korsmeyer SJ, Antonsson B, Jonas EA, Kinnally KW. Oligomeric Bax is a component of the putative cytochrome c release channel MAC, mitochondrial apoptosis-induced channel. Mol Biol Cell. 2005; 16: 2424-2432.

54. Ma SB, Nguyen TN, Tan I, Ninnis R, Iyer S, Stroud DA, Menard M, Kluck RM, Ryan MT, Dewson G. Bax targets mitochondria by distinct mechanisms before or during apoptotic cell death: a requirement for VDAC2 or Bak for efficient Bax apoptotic function. Cell Death Differ. 2014; 21: $1925-1935$.

55. Gratas C, Séry Q, Rabé M, Oliver L, Vallette FM. Bak and Mcl-1 are essential for Temozolomide induced cell death in human glioma. Oncotarget. 2014; 5: 2428-2435. 